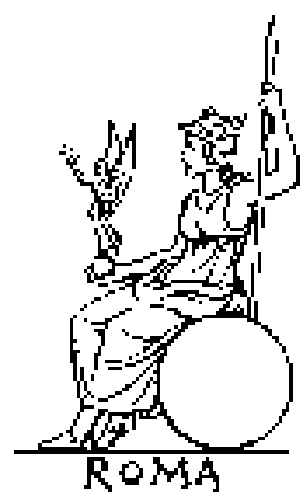

The Family of the Caristanii at Antioch in Pisidia

Author(s): G. L. Cheesman

Source: The Journal of Roman Studies, Vol. 3, Part 2 (1913), pp. 253-266

Published by: Society for the Promotion of Roman Studies

Stable URL: http://www.jstor.org/stable/296229

Accessed: 08/05/2014 23:55

Your use of the JSTOR archive indicates your acceptance of the Terms \& Conditions of Use, available at http://www.jstor.org/page/info/about/policies/terms.jsp

JSTOR is a not-for-profit service that helps scholars, researchers, and students discover, use, and build upon a wide range of content in a trusted digital archive. We use information technology and tools to increase productivity and facilitate new forms of scholarship. For more information about JSTOR, please contact support@ jstor.org. 


\section{THE FAMILY OF THE CARISTANII AT ANTIOCH IN PISIDIA.}

By G. L. CHEESMAN.

The following inscriptions from the Roman colony of Antioch in Pisidia, which form part of the fruits of expeditions made in I9I2 and I9I3, have been kindly communicated to me by Sir W. M. Ramsay. I am indebted to him and to Mr. J. G. C. Anderson for helping me to elucidate several of the points discussed below, and I have also to thank Mr. W. M. Calder for suggestions made at a later stage.

This group of inscriptions is particularly interesting since it deals with the fortunes of a single family, which clearly played an important part in the life of the colony from its foundation and steadily increased in power and influence throughout the succeeding century. The career of the first member of this family, C. Caristanius Fronto Caesianus Iulius, is given, more or less in detail, in the two following inscriptions :

(I.) Basis. In a wall in the courtyard of the school next door to the mosque in Kash Mahale ${ }^{\mathbf{1}}$ of Yalowadj : copied by Mr. J. G. C. Anderson and Sir W. M. Ramsay (fig. 42).

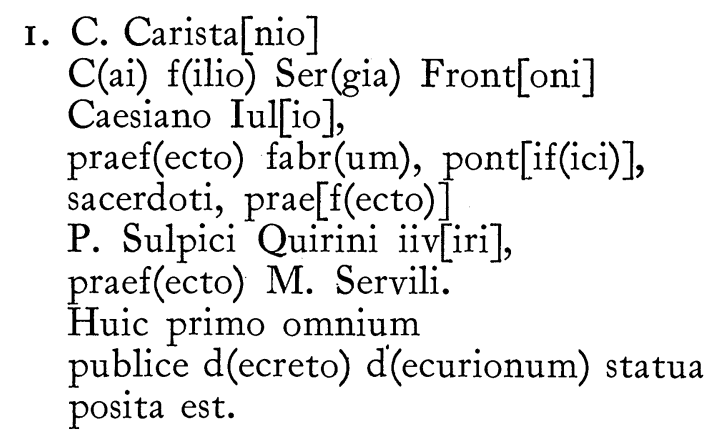

(2.) Perhaps a stone of a heroon. In a wall of a courtyard in the village Hissar-ardi, close to the site of Antioch. Copied by Sir W. M. Ramsay in rigr3.

1 On the twelve Mahalellar of Yalowadj see F.R.S. ii, p. ro2. 
2. C. Caristanio [C(ai) f(ilio) Ser(gia)]

Frontoni Caesiano

Iulio, praef(ecto) fabr(um), trib(uno) mil(itum)

leg(ionis) XIl Fulm(inatae), praef(ecto) coh(ortis) Bos[p(oranorum)],

pontif(ici), praef(ecto) P. Sulpici Quirini

iivir(i), praef(ecto) M. Servili, praef(ecto) ... .

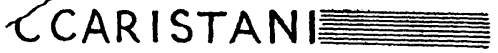 \\ FRONTONICAESIANO \\ IVLIO PRAEFFABRTRIBMIL \\ LEGXIIFVLMPRAEFCOHBOS琶 \\ PONTIFPRAEF PSVLPICIQVIRINI \\ IIVIR PRAEFMSERVILIPRAEF}

FIG. 4I. INSCRIPTION NO. 2.

The second inscription was probably erected at a later date than the first. - It includes two posts, those of tribunus militum and of praefectus cobortis, which no. I omits, and we may infer that these had not been held when the first inscription was erected, or they would certainly have been included. The arrangement of the second inscription is clearly that all posts in the imperial service are put first, municipal posts later. In both inscriptions it seems that minor municipal offices are omitted.

The approximate date of Caristanius' career is given by the statement that he was the first man to whom a statue was erected at Antioch at the public expense. The colony would not have been long in existence before so common a distinction was conferred upon more than one municipal dignitary. The foundation of Antioch is known to have occurred before IO B.c. Probably it took place either in 25 B.c. when the province of Galatia was organised after the death of Amyntas, or a few years later in 19 B.c. when Augustus himself visited the East. ${ }^{1}$ In view of this fact it is rather surprising to find that Caristanius possesses such an accumulation of cognomina, and includes Iulius among them. Professor Dessau has, however, pointed out a parallel case. ${ }^{2}$

The majority of the offices held by Caristanius, the three military posts and the two municipal priesthoods, need not detain us : they indicate that he belonged to a leading family in the town and was

\footnotetext{
1 For the date of the foundation of Antioch see Ramsay, Cities of St. Paul, p. 268, and Calder in F.R.S. ii, p. 8o. It is differentiated by its title from the other Pisidian colonies, which are known to have been founded at a rather later date. C.I.L. ii, 6843 , shows either that it was in existence at

least two years before the death of Drusus in 9 B.c. or that it was founded in II B.C.

2 In a letter quoted by Sir W. M. Ramsay in The Expositor for November, 1912. The parallels cited are C.I.L. iii, 551 ; xiv, 3606 ; vi, 1403 ; ix, 4197.
} 
presumably of equestrian rank. That he was " praef(ectus) coh(ortis) Bos[p(oranorum)]" is perhaps worth noting. This regiment must have been raised from the tribes living in the Crimea and round the shores of the sea of Azov, which were included in the client kingdom then ruled by Polemo I. Usually the client kings raised and controlled their own troops and supplied no contingents to the regular auxilia of the imperial army. It appears, however, from a passage in Tacitus that auxilia were raised in Thrace before

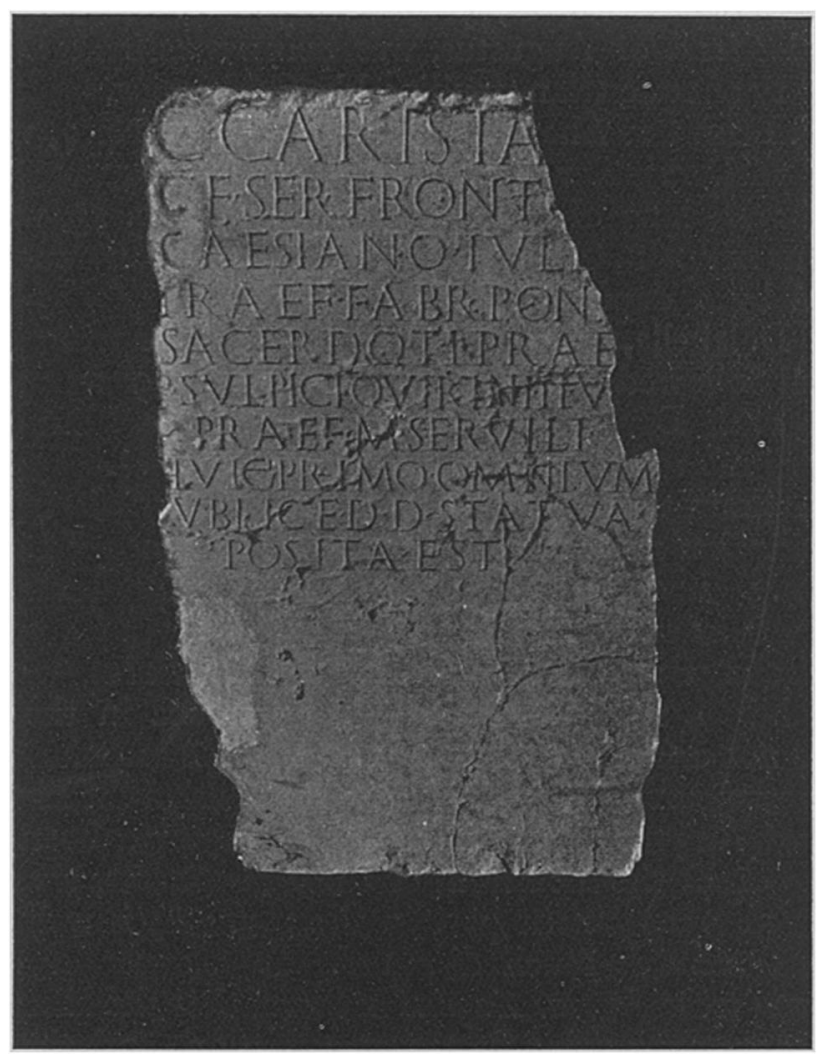

FIG. 42. INSCRIPTION NO. I (p. 253).

that country had been definitely annexed, and we must assume the same to have been the case here. ${ }^{1}$

But the most interesting feature of Caristanius' career is that he acted as representative of Q. Sulpicius Quirinius when the latter was titular duumvir of the colony. $\mathrm{He}$ also apparently stood in the same relation to M. Servilius, although in this case, as in that of

1 Tacitus, Annals, iv, 46: compare xii, 16. 
the praefectus of $\mathrm{Cn}$. Domitius Ahenobarbus mentioned below, the word duumvir is not added.

It was common, of course, particularly during the earlier empire, for the office of magistrate in a town of Italy or the provinces to be held in nominal fashion by the emperor himself or by a member of the imperial house, while the duties were performed by a deputy, praefectus. It is much rarer for private individuals to be found occupying such a position. Indeed, cases seem hardly to occur except in the reign of Augustus. ${ }^{1}$ The recorded examples are :

(I.) T. Statilius Taurus, consul in 36 B.c. and 26 в.c. and a confidential friend of Augustus, was quinquennalis at Dyrrhachium with a deputy of equestrian standing like Caristanius. ${ }^{2}$

(2.) Cn. Domitius Ahenobarbus, the father of Nero, was duumvir at Antioch with a similar deputy. ${ }^{3}$

(3.) Iuba II, king of Mauretania 25 B.C.-A.D. 23, was duumvir of two towns in Spain, Gades and Carthago Nova, and was presumably represented by a deputy. 4

(4.) P. Dolabella, who governed Dalmatia during the critical years which followed the great revolt of A.D. 6-9, was quinquennalis at Salonae with Drusus the son of Germanicus, 5 and a sometime magistrate of the town acted as praefectus to both.

(5.) Ti. Statilius Severus (otherwise unknown) is named on an Italian inscription not earlier than the second century A.D. as having a praefectus. ${ }^{6}$. But it is not clear that he was a duumvir or that the praefectus was a deputy to a duumvir. ${ }^{7}$

The circumstances which connected Quirinius with. Antioch and made him a figure of peculiar importance in the eyes of its citizens are not difficult to find. It was Quirinius who commanded the punitive expedition which finally avenged upon the Homonadenses the death of Amyntas, ${ }^{8}$ and since the colony had been called into existence to check the incursions of these marauders, we may assume that it played a prominent part in the war. As is well known, the date of this event is much disputed. It is generally agreed that Quirinius was twice legatus Augusti in Syria, that the Homonadensian war took place during his first administration, and that this must be put between his consulship in 12 в.c. and his appointment as adviser to Gaius Caesar in A.D. 2. Here certainty ends. Mommsen pointed out that Quinctilius Varus certainly governed Syria from 6 to 4 B.c. that he was preceded by Sentius Saturninus, who was

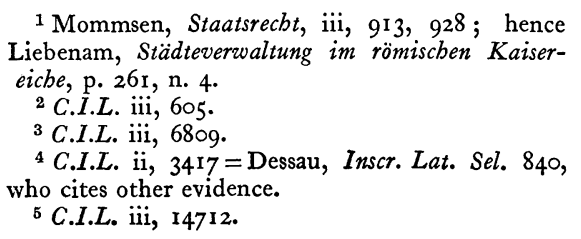

\footnotetext{
${ }^{6}$ C.I.L. x, 3910.

${ }^{7}$ A coin of Parium, which Liebenam, following Eckhel, wrongly attributes to Corinth, mentions Q. Barbatius as praefectus of the duoviri M. Barbatius and M. Acilius. It does not seem to me, however, that this case is parallel to those quoted above: cf. Brit. Mus. Cat. Corinth, introd. p. xxxix.

${ }^{8}$ Strabo, p. 569.
} 
in office in 7 в.c. and that between this date and 12 в.c. we have also to find room for a certain M. Titius, who is mentioned in a single passage of Josephus. ${ }^{1}$ On these grounds he wished to place Quirinius' first administration of Syria in the years $3^{-2}$ B.c. and to date the Homonadensian war to the same years. Since these arguments appeared, however, epigraphical evidence has been discovered which shows that one Cornutus Aquila, governor of Galatia, was laying out roads and military colonies in Pisidia in 6 в.с. ${ }^{2}$ This operation can hardly have been completed in eastern Pisidia so long as the Homonadenses were unconquered, but it would be the natural sequel to a successful war. We may compare the roadmaking activity of Cornelius Dolabella in Dalmatia after the suppression of the great revolt, in A.D. $90^{3}$ One might prefer, therefore, to date Quirinius' government by the war rather than (with Mommsen) to date the war by Quirinius' government. The war on this hypothesis was over before 6 B.c. and Quirinius governed Syria between 12 and 6 B.c. In order to accommodate Quirinius with the other legati of Syria at this period, two possibilities are open. He may have governed Syria before Sentius Saturninus, and either before or after M. Titius. In this case two at least of the three governors cannot have enjoyed their normal term of three years, but this objection is not serious, since the rule had many exceptions. There is, however, a possible alternative, which Sir W. M. Ramsay favours, namely, that during this war the importance of the responsibilities attached to the governorship of Syria caused the post to be divided between two legati. In A.D. 74 or 75 , for example, there seem to have been two legati Augusti in Africa charged with the special duty of revising the frontiers. ${ }^{4}$ On this supposition Quirinius may have been the colleague of either Titius or Saturninus.

For these reasons, then, it seems probable that Quirinius' command in the Homonadensian war, with which Caristanius' term of office as his praefectus was connected, followed immediately on his consulship or was given him only a year or two later. We have already seen that the first of the two inscriptions cited above favours as early a date as possible, and as the war, which probably lasted at least two years, seems, on the hypothesis already suggested, to have been over before 6 в.c. the years 8 and 7 B.c. would be the latest possible dates. 5

The considerations already advanced make it probable that in M. Servilius we should see another high official connected with the

\footnotetext{
1 Mommsen, Res gestae divi Augusti, pp. 16r-178.

${ }^{2}$ C.I.L. iii, $6974=12217, \quad 14185, \quad$ r 4401 ; W. M. Ramsay, Was Christ born at Betblebem, pp. 242-248. It seems clear that the man was Cornutus (not Cornelius) Aquila ; in any case, nothing else is known of him.

${ }^{3}$ C.I.L. iii, pp. 406, 407 .
}

\footnotetext{
4 A boundary stone is set up " per Rutilium Gallicum cos. pont. et Sentium Caecilianum praetorem legatos Aug." Cagnat, Comptes rendus de l'Aead. xxii (r894), p. $43 ; A . E$. 1912, no. I5 5 .

5 That the war lasted two years is probable from the two 'supplications' (Ramsay in Was Christ born in Betblebem, p. 23r).
} 
Homonadensian war. He may reasonably be identified with the M. Servilius who was consul in A.D. 3, and must have been at some period closely connected with Quirinius, on whose behalf he gave evidence in the suit which the latter brought against his wife Aemilia Lepida in A.D. 20. ${ }^{1}$ His career is otherwise unknown, but he may well have governed Galatia at the time of the Homonadensian war before Cornutus Aquila. In this case the appointment of Servilius and Quirinius as duoviri, possibly in successive years, and their selection of Caristanius as their praefectus, may be interpreted as a measure designed to put Antioch under something like a dictatorship for the purposes of the war without unduly violating its municipal liberties.

We have no direct evidence concerning the Caristanii of Antioch during the next sixty years, but an inscription, which deals with some of their dependants, shows that the family was still flourishing at Antioch two generations later:

(3.) On a small round cippus, found in r9r2, during excavations at the shrine of Mên Askaênos apud Antiocbiam. ${ }^{2}$ From a squeeze.


$T I \cdot C L A V D I V$
EPINICVS.
PROC.ET.PRAE
GVSTATOR.ET
ASE CRETIS.AVG
VI.VIR.A VG.C.C.
D.D.EX.MANDATK
CARISTANIOR.
DROSERAE. ET.
MILETI.PARENT
VM. SVORVM
POSVIT

FIG. 43 .

It will be noted that Epinicus bears a gentile name differing from that of his parents. - Possibly he was born a slave in the possession of some Caristanius, and was then given or sold to the emperor. After receiving freedom from the latter and assuming in consequence the name of Tiberius Claudius, he would return to his native town to find that his parents had in the interval been freed by their owner and had duly assumed the name of Caristanius. Much the same 
situation seems to be recorded on an Italian inscription dealing with another imperial praegustator, Ti. Claudius Bucolas. ${ }^{1}$ This man mentions that his mother's name was Sulpicia Cantabra, from which it would appear that, while he had been freed by the emperor Claudius, she had been in the service of, and been freed by, some member of a family of Sulpicii. Sir W. M. Ramsay suggests ${ }^{2}$ an alternative explanation, namely, that, with the transference of property from a member of the Caristanian family to the emperor, the latter had also acquired the rights of patronus over the parents of Epinicus, who had not, however, changed their name and taken that of their new master. On this theory, Epinicus would either have been manumitted after the transference and taken the emperor's name, or have changed his name on beginning an active career in the domus. Hirschfeld quotes cases of imperial freedmen who apparently bear the names of former patroni, and suggests that in others names may have been changed.

As regards the career of Epinicus, we know that the praegustatores of Claudius were sufficiently numerous to form a collegium under a procurator drawn also from among the imperial freedmen. ${ }^{3}$ The post of a secretis is unknown until the sixth century, from which period the holder of it appears as a high official. That is obviously not the case here, and we should perhaps rather seek a parallel in the "libertum ex secretioribus ministeriis," who was reported to have been sent by Domitian on a confidential mission in connexion with Agricola's position in Britain. ${ }^{4}$

In what capacity Epinicus was procurator cannot be determined from the inscription. Probably the post marks the culmination, not the beginning, of his career, for we can hardly imagine that any procurator ranked below the praegustatores. He may, of course, have been connected with the administration of the imperial estates in the neighbourhood of Antioch. It is equally likely, however, that his duties had lain within the domus and that he merely retired with the title to Antioch to enjoy in his old home the prestige naturally attaching to an ex-imperial freedman, which did in fact secure for him, as this inscription shows, the position of Augustalis.

He was probably not the only ex-dependent of the Caristanii to play a part in the social life of the town. An already published inscription gives us a list of names, apparently of freedmen of the family, who would probably be found figuring in some more or less important capacity if the whole text of the document were preserved. 5

${ }^{1}$ C.I.L. xi, 3612.

2 He bases his theory on Hirschfeld, Verwaltungsbeamten, p. 458 , n. I, who quotes, for examples, C. Pontius Aug. lib. Gemellus and M. Macrius Trophimus Aug. lib.
${ }^{3}$ C.I.L. vi, 9003,9004 .

${ }^{4}$ Tacitus, Agricola, 40 .

5 C.I.L. iii, 6852. The names are Hamyrus, Agapetus, Haptus, Faustus, Valens, Pothus, Flaccus, Felix, all being Gaii Caristanii. 
A fourth inscription, dealing with what we may call-for reasons which will appear later-the fourth generation of the Caristanii, shows us a member of this provincial family taking his place in the highest rank of the governing class.

(4.) In Debbagh Khane of Eski Mahale in Yalowadj. Copied by Mr. W. M. Calder and Sir W. M. Ramsay in I9I2, and revised in part by the latter in I9r3.

\section{C.CARIS NIOCC.F.SER.F TONI.TRB.MIL.PI㤩 EQ.AL:BOSP.A DL CTOOIN.SENATV - INTEE TRBVNIC.PROMOTO.IN ER.PRAEORIOS·LEG. PRO PR.PONTI-E·BITYN.LEG IMP DIVI.VESPASIAN·AVG - LEG IX HISPANAE-IN.BRITANN LEG.PROPR.IMP.DIVI.TITI. CAES-AVG.E.IMP.DOMITIA CAES.AVG.PROVINC. PAM PHYLIAE·E.LYCIAE.PATRO NO COL}

\section{T CARISTANIVSCAL PVRNIANVSRVFVS OBMERITAEIVSHC}

4. C. Carist $[a-]$ nio $C$ (ai) $f($ ilio) Ser(gia) F[rontoni, trib(uno) mil(itum), p[raef(ecto)] eq(uitum) al(ae) Bosp(oranorum), adl[e-cto in senatu(m) inte[r] tribunic(ios), promoto inter praetorios, leg(ato) pro pr(aetore) Ponti et Bithyn(iae), leg(ato) imp(eratoris)

divi Vespasian(i) Aug(usti) leg(ionis) IX Hispanae in Britann(ia), leg(ato) pro pr(aetore) imp(eratoris) divi Titi

Caes(aris) Aug(usti) et imp(eratoris) Domitian(i)

Caes(aris) Aug(usti) provinc(iae) Pamphyliae et Lyciae, patrono col(oniae)

\section{T. Caristanius Cal-} purnianus Rufus ob merita eius h(onoris) c(ausa).

FIG. 44 .

The Caristanius Fronto of this inscription was not altogether unknown previously. Greek texts from various cities in Lycia had already shown that he governed that province, and his administration had been conjecturally and correctly assigned to the reign of Domitian. ${ }^{1}$ A fragmentary inscription found near Synnada in Phrygia also suggests that he went on to be proconsul of Asia. ${ }^{2}$ This new inscription, which was obviously set up before Domitian's

1 I.G.R. iii, 512, from Cadyanda; 555, from Tlos, and 729, in which the name and titles of Domitian were correctly restored, from Limyra: ibid. 600, from Antioch, for which see below, mentions his wife, and 5 I I a son, C. Caristanius Paulinus. ${ }^{2}$ C.I.L. iii, 141924. 
death, gives us the details of his whole career so far as his governorship of Lycia. . Caristanius embarked on the equestrian " cursus honorum," omitted, as was often done at this period, the post of praefectus cobortis, ${ }^{1}$ and passed at once to the remaining two offices of the militia equestris, those of tribunus legionis angusticlavius and praefectus alae. It is interesting to note that, like his ancestor in the reign of Augustus, he commanded a regiment of Bosporani. ${ }^{2}$ After proceeding only thus far in the equestrian career, that is to say, while he was still a comparatively young man, Caristanius received the honour of being " adlected" into the senate. Placed at first inter tribunicios, he was then promoted to the higher grade of praetorius, and thus qualified for the official posts open to ex-praetors without the trouble and expense of being actually forced to hold the praetorship. ${ }^{3}$ The first post which he held in the senatorial cursus, that of legatus to the senatorial governor of Pontus and Bithynia, seems to fall within the reign of Vespasian, so that we are probably safe in assuming that Caristanius, like so many other provincials, was admitted to the senate during the famous joint-censorship of Vespasian and Titus in A.D. 73-4. From Bithynia he passed to Britain, where he commanded the ninth legion and must have served under Agricola at the beginning of the latter's long term of administration. Recalled from Britain he was sent, some time before the death of Titus in September, 8I, to govern the province of Lycia-Pamphylia, and remained there at the beginning of the following reign. As Domitian is not given the title Germanicus in the inscription, it was probably set up before the end of 83 , and therefore while Caristanius was still governing his province. As to the dates of his consulship and his proconsulship of Asia we have no information. But, if we assume that he held the consulship soon after his return from Lycia, and proceeded to Asia after the then usual interval, ${ }^{4}$ his term of administration there would fall near the accession of Trajan.

The family connexions of this Caristanius are further illustrated by a Greek inscription from Antioch, most of the text of which, first published by Sterrett, ${ }^{5}$ is reprinted here with some revised readings obtained this year by Sir W. M. Ramsay after a careful inspection of the stone.

\footnotetext{
${ }^{1}$ For the omission of the post of praefectus cobortis at this period see von Domaszewski, Rangordnung des römiscben Heeres, $\mathrm{p}$ 122, ff.

${ }^{2}$ The language of Tacitus, Annals, xii, I6, where the troops of the Bosporan kingdom are clearly distinguished from the regular auxilia, might incline us to place the creation of this ala after the year A.D. 63 , when the kingdom seems to have been taken for a time under more direct imperial control. Inscription 2, cited above,
}

shows, however, that one cohort, at least, of Bosporani had been enrolled in the reign of Augustus. 3 The phrase used in the inscription is rare. But the same process is indicated by such expressions as adlectus inter praetorios, tribunicios, quaestorios: cf. Hirschfeld op. cit. p. 4r5, n. 2, against Mommsen who gives a different interpretation of them.

4 Mommsen, Staatsrecbt, ii, $25 \mathrm{x}$.

5 J. R. Sitlington Sterrett, Epigrapbical journey in Asia Minor, n. 108, cf. I.G.R. iii, 600. 
5. $[\tau \grave{\eta} \nu \kappa \rho a \tau i \sigma \tau \eta \nu \Sigma \epsilon-$

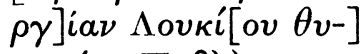

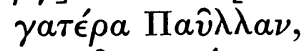

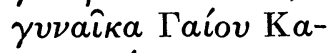

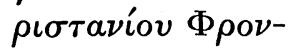
$\tau \hat{\omega} \nu \circ \pi \pi \epsilon \sigma \beta \epsilon v_{-}^{-}$

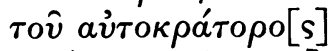

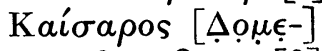

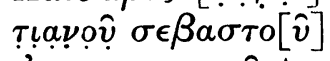

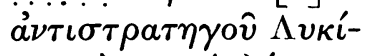

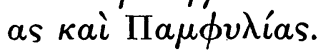

Last two lines :

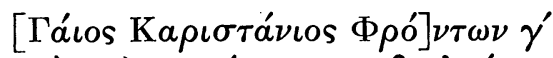

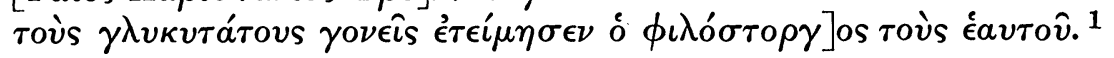

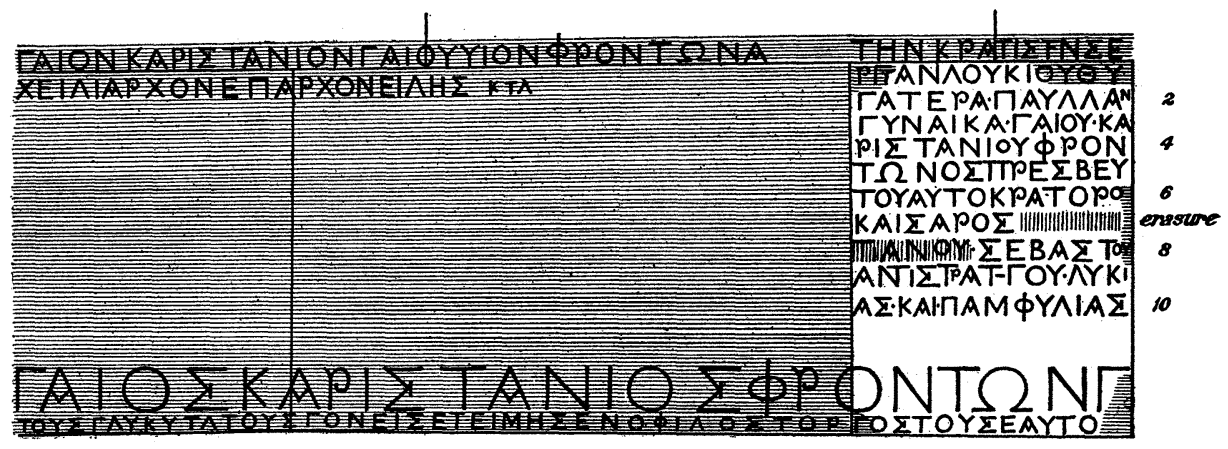

FIG. 45. INSCRIPTION NO. 5 .

N.B.-Horizontal shading indicates loss or break of the stone; vertical shading indicates erasure. TIANO $\Upsilon$ can be read in 8 , although $\triangle \mathrm{OME}$ 'has wholly disappeared in 7. The shape of the lost stones is restored on the supposition that broad and narrow stones alternated as " headers" and "stretchers."

The correct restoration of this inscription involves the consideration of so many technical points only to be appreciated by one who has actually seen the stone that I have availed myself of Sir W. M. Ramsay's permission to print here his own description of it. ${ }^{2}$

"The engraving of this inscription is deep, regular in its own fashion, and clear, except where the surface, which is generally well preserved, is broken. The form of the letters is unusual in my experience, but uniform throughout. These characteristics facilitate

1 [In Phrygian Greek texts $\gamma o \nu \epsilon \hat{\text { s }}$ is the common accusative form; but the correct form, rovtas, occurs, and also such monstra as roviñas.-W.M.R.]

2 Owing to the position of the stone it was impossible for a photograph of it to be secured. 
restoration, since they enable one to speak with great confidence about what must have been the case where the surface is injured.

"Professor Sterrett's copy is correct except in omitting the two initial upright strokes of 1 . I, and the small $\nu$ of $\Pi \alpha \hat{v} \lambda \lambda \alpha \nu$, but the type used by his printer was, of course, quite incapable of representing the very distinctive character and arrangement of the letters. Still, his published copy makes it possible to understand the original form of the whole, and in I897 I submitted to Professor Mommsen a restoration which, with one slight improvement, he accepted. The arrangement of the original was one of which several examples are known at Antioch, and will be found repeated in a recently discovered inscription in honour of P. Calvisius Ruso, governor of Galatia, and his wife. ${ }^{1}$ Both inscriptions extended over more than one stone in the wall of a building, and both were arranged in two columns, one devoted to the husband and the other to his wife. Underneath the two columns in the inscription of $\mathrm{C}$. Caristanius and his wife' was a line giving the name of the dedicator in very large letters, and another line, squeezed in apparently as an afterthought and engraved in very small letters, stating the relations of the dedicant to the persons honoured. I may add that Mommsen, in his letter dated September I6th, I897, acknowledged that in quoting this inscription under C.I.L. iii, 6852, he had not rightly understood its form, and that he accepted all that has been said here as certain and plainly evident.

"Beyond this I conjectured, with Mommsen's approval, that the letter following $\mathrm{ONT} \Omega \mathrm{N}$ in 1. I I was originally $\mathrm{E}$, which is quite in accordance with Sterrett's copy, and is even suggested by the marks which he appends to his symbol $\Gamma$ in place of $\mathbf{E}$. I also conjectured, with Mommsen's approval, that the name of the dedicator

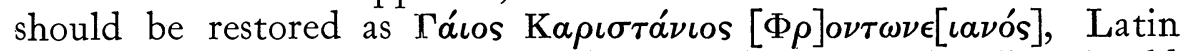
Frontonianus, that he was a freedman, and that the last line should be restored [aं $\left.\pi \epsilon \lambda \epsilon v^{\prime} \theta \epsilon \rho\right]$ os. The same idea may readily suggest itself to others, since it rises so naturally from the marks in Sterrett's copy, and I therefore add that with this restoration in my mind I examined the stone carefully on two successive days in I9I3, to find

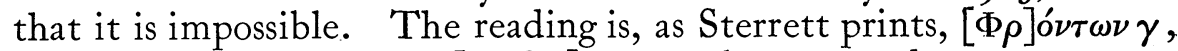
although his restoration $\gamma[v \nu \alpha \hat{i} \kappa \iota]$ cannot be accepted.

"To arrive at the true interpretation we must observe, in the first place, that there is not only a stop before the $\Gamma$ but possibly one after it also, although the surface is blurred, as Sterrett's published copy

\footnotetext{
1 This inscription is published below, pp. $301, \mathrm{ff}$. with a full commentary by Professor Dessau.

2 There was not a similar subscribed line or lines in the inscription of Ruso, unless it was separated
}

by a distinctly broader gap from the two columns. It may have been placed at the top, but in any case the circumstances of the dedication must have been stated, as this is customary. The name of the dedicator is often in larger letters. 
indicates. Secondly, even if there is no stop, ${ }^{1} \mathrm{~T}$ is certainly the end of the line. Before I saw the stone, and studied the analogy of similar examples, I thought that $\Phi \rho o \nu \tau \omega \nu \epsilon \iota \nu$ ós was written in this line; now I feel confident that the subscribed line or lines correspond in extent to the two superimposed columns, and do not extend beyond the breadth marked out by them.

"Given then that the line ended ONT $\Omega N \cdot \Gamma$ the rest of the name of

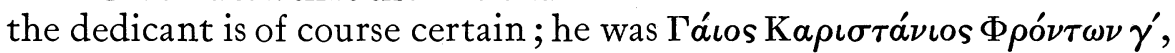
i.e. son and grandson of C. Caristanius Fronto. That the praenomen should be written in full, not abbreviated to $\Gamma$, is probable for several reasons. (I) All other praenomina are given in full in this inscription; (2) The dedicant deliberately affects the Greek style, and would therefore use the Greek forms ${ }^{2}$ rather than the Roman custom of abbreviation; (3) the career of the father must evidently have been given in full, since even in his wife's titulus his present office is stated, and this requires a considerable breadth for the left-hand titulus; (4) in the similar inscription of Ruso and his wife, the left-hand titulus is in fact very much broader than the titulus of the wife. The last line is squeezed in at the bottom of the stone; evidently the engraver did not wish to trespass on the stones below, and this suggests that the course underneath was unsuitable, either because of its shape, or for some other reason. The missing words cannot be supplied with certainty, but they must have been of the general tenour of those given. The emphasised repetition of $\tau$ cov̀s $\dot{\epsilon} a v \tau o \hat{v}$ at the end of the last line seems awkward, but is needed after the

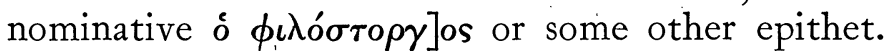

"One further point remains, to determine the name of Caristanius' wife. The first preserved letter is the lower half of an upright stroke which might be part of $\mathbf{I}$ or $\Gamma$ or $\mathrm{T}$. The supposition that it might be the right limb of $\Pi$, or part of any other letter, is eliminated by the facts regarding the second letter and by the shape of these letters in other parts of the inscription. The second letter is a small I not reaching to the top of the line. This is beyond question; the symbol is complete and the top clearly marked. The name, therefore, ended in -ıa. The usage in this inscription, and generally, makes it certain that the employment of a small iota near the beginning of the line can be explained only through the supposition that it came under the extended bar of a $\Gamma$ or $T$. Both these letters, especially the $\Gamma$, had a very long horizontal bar. ${ }^{3}$ The name, therefore, ended in $\tau^{\prime} \boldsymbol{i} a$ or in ria.

"There is room for one letter, but not a broad one, before the broken $\mathrm{T}$ or $\mathrm{\Gamma} .{ }^{4}$ First let us suppose the broken letter to be T. In the

\footnotetext{
1 The mark indicating the end of a word is usually omitted when the word ends a line.

${ }^{2}$ Greek epigraphy abhors abbreviations.
}

\footnotetext{
${ }^{3} \mathrm{~T}$ is in form like two sides of a square.

4 The engraver makes certain letters very broad, especially II, T, $\Omega, \Sigma$.
} 
usage that this engraver observes there is not room for $\mathbf{A}$ before the broken $\mathrm{T}$. The right lower tip of $\mathrm{A}$ would necessarily come much closer to $\mathrm{T}$ than he permits. Moreover the left half of the horizontal bar of $\mathbf{T}$ would approach near the beginning of the line, and the apex of A would have to come under it. This engraver, however, never puts his $\mathrm{A}$ under the cover of the limb of his T. Further, these would be the first three letters of a line, and it is inconsistent with the character of this engraver to suppose that he crowded three letters in such a way at this point. The supposition of a name ending

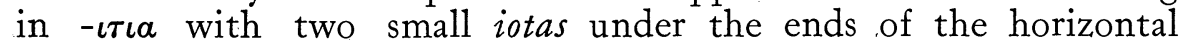
bar of $\mathbf{T}$ at the beginning of a line is also quite inconsistent with this engraver's habit. $\Sigma$ or $\Omega$ are also inconsistent, since he makes both these letters very broad-quite remarkably so.

"We are reduced, therefore, to the supposition that the name ended not in $\tau^{\prime} a$ but in $\gamma^{\prime} a$. Before the $\Gamma$ there is just room for P, since $\mathrm{P}$ is a letter of medium size on this stone, sometimes even smaller. Finally, therefore, in trying through all possible combinations with the stone before me I came to the conclusion that the name must be $[\Sigma \epsilon \rho] \gamma^{\prime} a a^{\Pi} a \hat{v} \lambda \lambda \alpha^{1}{ }^{1}$ "

Sir W. M. Ramsay's restoration of the name Sergia Paulla is further supported by an unpublished fragment of an inscription from Antioch, dating probably from the middle or latter half of the first century, which mentions a man of senatorial rank named L. Sergius L. f. Paullus filius (i.e. " the younger"). The connexion of this man with Antioch cannot be determined without further evidence, but it seems most likely that he was governor of Galatia, as there was no officer of senatorial rank in the province except the governor.

In any case it seems probable that it was to his sister or daughter that Caristanius was married, and that this marriage connexion with a senatorial family may have aided his advancement. The fact that Paullus is called " the younger," for " filius" corresponds to the common Greek expression $\nu$ éos or $\nu \epsilon \omega \dot{\tau} \epsilon \in \rho$ s, shows that his father was also known in the Eastern provinces, and may probably be identified with the well-known proconsul of Cyprus in A.D. 46-47.

Another point in the family tree of the Caristanii is illustrated by the $\Gamma$ which C. Caristanius Fronto appends to his name, thereby implying that it was also borne by his father and grandfather. His father, the legate of Lycia, was, as we have seen, probably born about A.D. 40, and the date of bis father's birth may be placed about thirty years earlier, about A.D. IO. The latter cannot then have been the son of C. Caristanius Fronto Caesianus, for in that case the last C. Caristanius would have described himself as $\delta^{\prime}$ not $\gamma^{\prime}$, and we

${ }^{1}$ As an alternative it must be admitted that [Ovंa $\left.\lambda\right] \gamma i a$ is epigraphically possible, but the name Valgia Paulla seems indefensible. 
must either suppose an intervening ancestor, who bore a different praenomen, or imagine that the legate of Lycia was not descended in a direct line from the deputy of Quirinius. Be that as it may, the fact is undoubted that he belonged to the same family, which thus rose in four generations from a position of little more than municipal importance to the highest legitimate aim of a Roman's ambition.

It is probable that Caristanius the consul had, as we have seen, a son of the same name as himself, and another named C. Caristanius Paulinus is referred to on a Greek inscription. ${ }^{1}$ Possibly also the T. Caristanius Calpurnianus of (3) was a third son. Further than this, however, the family cannot be traced, unless the [C]aristanius Iustianus, who commanded a cohort of Hamii on the Antonine Wall in Britain, be considered a member of it. ${ }^{2}$ The origin of the family is equally obscure. Professor Haverfield, in commenting on the British inscription, refers to three other mentions of the name, and I have not been able to add to the list. The first is on a seal-ring from Naples inscribed c. CARISTAN CAEseti RUFI, which is not very enlightening. ${ }^{3}$ The other two are sepulchral inscriptions of Greek freedmen, C. Caristanius Hermaescus and C. Caristanius Myron, from Capua and Rome, the former being possibly of the republican period. ${ }^{4}$ It seems likely, then, that the family was of Italian origin, but had never risen into prominence there. One of its members was presumably enrolled in the army during the civil wars, and included among the veterans settled in the 'colonia' at Antioch. 'The fact that so obscure a family in so remote a provincial outpost could rise so far in four generations is a striking illustration of the possibilities offered by the imperial régime.

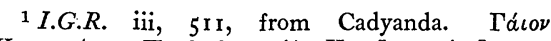

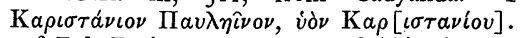

${ }^{2} E p h . E p$. ix, n. I242; Haverfield in the Antonine Wall Report, p. 153 .
${ }^{3}$ C.I.L. x, 8059 (39).

${ }^{4}$ C.I.L. x, 4417; vi, 14406 . That Hermaescus was a freedman is definitely mentioned; Myron's status I infer from his name. 